\title{
VEGF and FGF-2 Released In Palatal Suture after Rapid Maxillary Expansion (RME)
}

\author{
Adriana Sasso Stuani ${ }^{1} \oplus$, Paula Regina Ávila Silvano ${ }^{2}$, Maya Fernanda \\ Manfrin Arnez ${ }^{2}{ }^{\circ}$, Paôla Caroline da Silva Mira ${ }^{2}{ }^{-}$, Maria Cecilia Gorita ${ }^{2}$, \\ Patrícia Maria Monteiro ${ }^{\oplus}$, Mirian Aiko Nakame Marsumoto² ${ }^{-}$, Mario Hiroshi

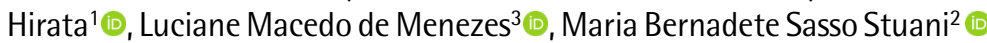

\author{
${ }^{1}$ Department of Clinical and \\ Toxicological Analysis, School \\ of Pharmaceutical Sciences, \\ USP - Universidade de São \\ Paulo, São Paulo, SP, Brazil \\ ${ }^{2}$ Department of Orthodontic, \\ School of Dentistry of Ribeirao \\ Preto, USP - Universidade de São \\ Paulo, Ribeirao Preto, SP, Brazil \\ ${ }^{3}$ Department of Orthodontics, Dental \\ Program - School of Health and \\ Life Sciences, PUCRS - Pontifícia \\ Universidade Católica do Rio Grande \\ do Sul, Porto Alegre, RS, Brazil \\ Correspondence: Prof. Dr Maria \\ Bernadete Sasso, Av do Cafe, s/n, \\ 14040-904 Ribeirao Preto, SP, \\ Brasil. Tel: +55-16-3315-4105. \\ e-mail: bernadete@forp.usp.br
}

Key Words: angiogenic growth factors, VEGF, FGF-2, orthodontics, rapid maxillary expansion.

\begin{abstract}
Vascular endothelial growth factor (VEGF) and basic fibroblast growth factor (FGF-2) have the ability to increase vascular proliferation and permeability. The aim of this study was to quantify the release of two diffusible angiogenic growth factors (VEGF and FGF-2) after rapid maxillary expansion (RME). Thirty animals were randomly assigned to two groups. Control group (5 rats - intact suture) and Experimental groups (25 rats with RME) which were evaluated in different periods of treatment. Five animals were euthanized in different periods of healing at $0,1,2,3,5$ and 7 days after RME. RT-PCR was used to evaluate the gene expression of angiogenic growth factors released on different periods of study. Data were submitted to statistical analysis using ANOVA followed by Tukey test and significance was assumed at $\alpha=0.05$. RT-PCR showed that mRNAs of VEGF and FGF-2 were expressed in intact palatal suture tissue. mRNAs of VEGF and FGF-2 was upregulated in early periods ( $24 \mathrm{~h})$ after $\operatorname{RME}(\mathrm{p}<0.001$ and $p<0.01$, respectively). The molecular levels of VEGF never returned to its original baseline values, and FGF-2 expression decreased up to day $5(p<0.001)$ and suddenly increased at day 7, returning to its original level. RME increased VEGF secretion, but decreased FGF-2 secretion when compared to intact tissue. The results showed that these angiogenic growth factors are released and regulated in the palatal suture tissue after RME and could make an important contribution to the knowledge of overall reparative response of the suture tissue during the bone remodeling process.
\end{abstract}

\section{Introduction}

Angiogenesis is the process of new blood vessel development from pre-existing capillaries (1). It is found in different situations, such as embryonic tissues, inflammatory processes, wound healing and repair, and pathological processes that involve blood vessel growth such as tumorigenesis (1). Angiogenesis is a complex process with extracellular matrix remodeling, secretion of proteolytic enzymes, endothelial cell migration and proliferation, capillary differentiation, and anastomosis (1); and it is a critical step of wound healing. This process is regulated by interplay of several cytokines growth factors (GFs) (2). A large number of angiogenic inducers have already been identified, including vascular endothelial growth factor (VEGF) and basic fibroblast growth factor (FGF-2) (1). There are considerable evidences to indicate that VEGF and FGF-2 play a critical role in neovascularization $(1,3)$.
Fibroblast Growth Factor-2 (FGF-2), also named basic FGF (bFGF) is known to stimulate angiogenesis in vivo (4), and is thought to play a significant role in neovascularisation of damaged or traumatised tissue (5). It shows increased expression in hypoxic conditions and during wound healing. FGF-2 enhances endothelial cell proliferation and induces endothelial cell sprouting (6).

Vascular endothelial growth factor (VEGF) also known as the vascular permeability factor (VPF), plays a central role in angiogenesis, promoting the formation of new capillaries (7), although it was initially described as an inducer of vascular permeability (8). VEGF is required for endothelial cell differentiation during vasculogenesis, and for the sprouting of new capillaries from pre-existing vessels during development (9). VEGF is considered a specific mitogenic factor for vascular endothelial cells and also shows a paracrine function on environment. VEGF is produced by various cells, such as tumor cells (10), 
and smooth-muscle cells and pericytes around vascular endothelium (11). Studies also indicated that VEGF induced the differentiation of osteoblasts (12).

VEGF has been found to be 50,000 times more potent than histamine in enhancing permeability to fluids and proteins (2). VEGF also plays a critical role in angiogenesis and neovascularization, which actually can increase and extend the severity of the inflammatory processes because of the increased transport of inflammatory cells, nutrients, and oxygen to the site of inflammation (13).

Previous studies indicate that a combination of angiogenic growth factors are released following orthodontic force, orthopedic force, (14) and that these factors are diffusible and able to induce angiogenesis in other tissues (14). So the angiogenesis (or neovascularization) is a critical part of the wound healing process in all tissues and local angiogenesis is a prerequisite for successful repair in the suture and bone after rapid maxillary expansion (RME). So after RME, the repair and reorganization of the capillary plexus appears necessary for a specific bone response. However, the nature and origin of the angiogenic stimuli in these reparative states are unclear.

Investigation of the growth factors released and their role in the angiogenic response of the palatal suture to orthodontic force is actually required. It is well known that vascularization is very important during bone remodeling and tooth movement. After the angiogenesis process, which is previously required for bone formation in palatal sutural, RME also induce a mechanical stress that resulting in bone remodeling followed by apposition between the palatal suture borders, as a similar reparative process found in other bone tissues. Alveolar bone remodeling consists of an interaction of bone resorption by osteoclasts with bone formation by osteoblasts (15).

A research about the growth factors is required to improve the knowledge about which growth factors are released, as well as their roles in the angiogenic response of the palatal suture after orthopedic force. Vascularization is the crucial process during bone rermodeling and tooth movement. The aim of this study was to evaluate the expression of two angiogenic growth factors (VEGF and FGF-2) in intact suture and RME. We used RME in rats on different periods of treatment and quantified the vascular growth factors involved using the RT-PCR method.

\section{Material and Methods}

\section{Study Design}

The study was approved by the Committee of Ethics in Animal Reserch, School of Dentistry, Ribeirão Preto/ University of São Paulo, Brazil. A total of 30 wistar Albinus male rats (fifteen-week-old) were used. The animals were housed in an air-conditioned room, automatically controlled temperature $\left(20-23^{\circ} \mathrm{C}\right)$ and $12 / 12 \mathrm{~h} \mathrm{light/dark}$ cycle and 50\% relative humidity. The animals received a standard pelleted laboratory diet and water ad libitum. The rats were randomly assigned to two groups. Control group ( $n=5$ with intact suture) euthanized at day 0 , and Experimental groups ( $n=25$, with 5 animals in each period of treatment) with midpalatal suture expansion, was euthanized at day 1, 2, 3, 5 and 7 after RME procedure. The animals were weighed during all periods of evaluation in order to appoint some possible effects of animals preparation or RME procedure.

\section{Anesthesia and RME Procedure}

The animals were anesthetized with a combination of ketamine (Agener ${ }^{\circledR}, 40 \mathrm{mg} / \mathrm{Kg}$ ) and xylazine (Syntec ${ }^{\circledR}$, $20 \mathrm{mg} / \mathrm{Kg})$ intramuscularly at $1: 2$ ratio $(1 \mathrm{~mL} / \mathrm{kg}$ body weight) in all procedures. The experimental animals were submitted to RME for different periods of evaluation. The immediate expansion of midpalatal suture was performed by inserting a $1.5 \mathrm{~mm}$-thick circular metal ring fabricated from $0.5 \mathrm{~mm}$ diameter stainless steel orthodontic wire (Dental Morelli Ltda ${ }^{\circledR}$, Sorocaba, SP, Brazil). This device was inserted between the maxillary incisors (Fig. 1) to induce the maximum expansion rate in the midpalatal suture. The initial magnitude force used in the experiments was 0.56 $\mathrm{N}$ (measured by a Dontrix force gauge, GAC International Inc.). A occlusal radiograph was performed to confirm the opening of midpalatal suture. This appliance was kept in position with light cured adhesive $\left(3 \mathrm{M}^{\circledR}\right.$ Unitek, Monrovia, CA). Five animals were euthanized in each experimental periods with an overdose of Ketamine and Xylazine anesthetic. The tissue samples from palatal suture were obtained aseptically and kept in eppendorfs with
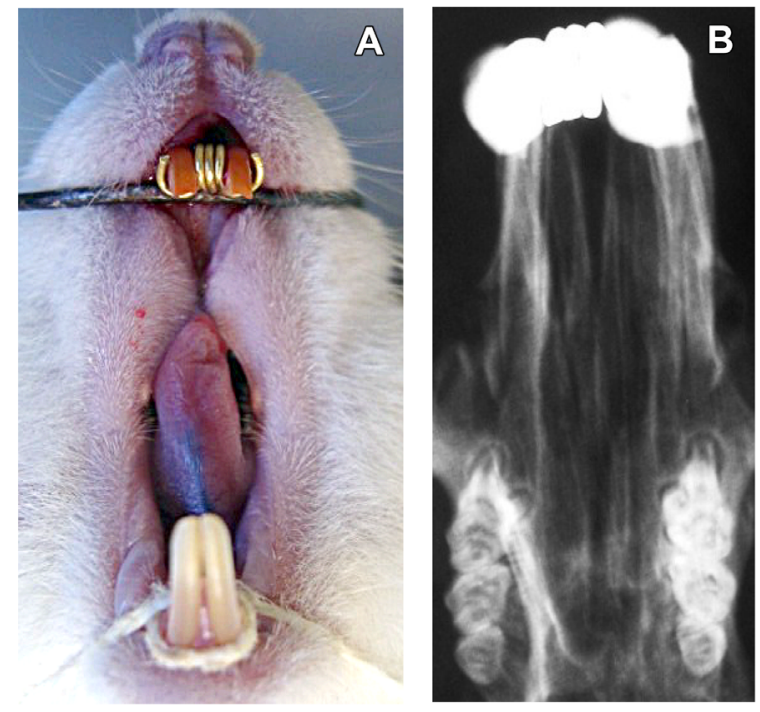

Figure 1. A: RME was performed in midpalatal suture by inserting a circular metal ring $(1.5 \mathrm{~mm}$ - thickness X $0.5 \mathrm{~mm}$ - diameter $)$ between the maxillary incisors. B: Occlusal radiograph after RME midpalatal suture. 
RNAlater ${ }^{\circledR}$ (Ambion Inc., Austin, TX, USA) and stored at $-80^{\circ} \mathrm{C}$ temperature.

\section{RNA Extraction and cDNA Synthesis}

The connective tissue between palatal bones and palatal bone edges of the suture were removed to analysis. We removed all gingival tissue and all this area was dissected to reach the deep planes and collect the tissue of study. Total RNA was extracted from the sample tissues using the SV Total RNA Isolation System (Promega, Madison, WI). The expression of RNA was measured using GeneQuant 1300 device (Amersham Biosciences, Piscataway, New Jersey). The RNA purity was determined from A260/A280. The total RNA was then stored at $-80^{\circ} \mathrm{C}$. Complementary DNA (cDNA) was synthesized using $1 \mu \mathrm{g}$ of RNA through a reverse transcription reaction using $1 \mu \mathrm{L}$ reverse transcriptase (High Capacity cDNA Reverse Transcription Kit, Applied BioSystems) and $1 \mu \mathrm{L}$ of RNAse inhibitor (Appied BioSystems). Reverse transcriptase reactions were carried out in Eppendorf Mastercycler Gradient (Eppendorf, Milan, Italy) at $25^{\circ} \mathrm{C}$ for $10 \mathrm{~min}, 37^{\circ} \mathrm{C}$ for $120 \mathrm{~min}$ and $85^{\circ} \mathrm{C}$ for $5 \mathrm{~min}$. The cDNA was then stored at $-20^{\circ} \mathrm{C}$.

TaqMan real-time quantitative reverse transcriptase polymerase chain reaction

Reverse-transcription (RT)-PCR products were analyzed by quantitative real-time (RT-PCR) in TaqMan Gene Expression Assays (Applied Biosystems, Foster City, California) for the target genes: VEGF (Rn 01511604-m1 $101 \mathrm{pb}$ ) and FGF-2 (Rn 00570809-m1 63pb). The TaqMan Endogenous Control (Applied Biosystems) for the target gene GAPDH (glyceraldehydes adenosine-phosphate dehydrogenase) was used as the reference gene. All assays were run four times to ensure reproducibility with comparable results and water was used as the negative control. All PCR reactions were performed by using CFX 96 Real-time PCR detection system (Bio-rad, California,

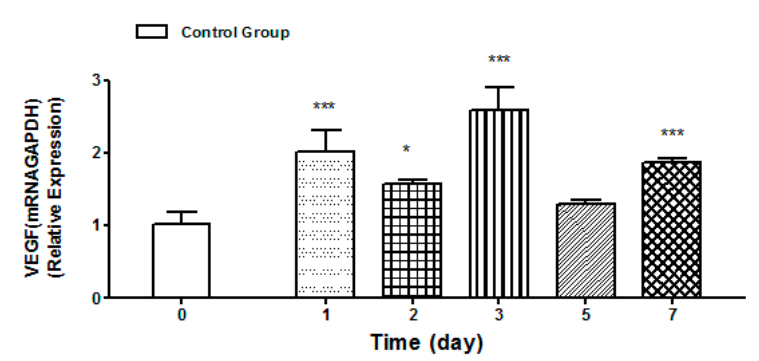

Figure 2. VEGF mRNA expression. mRNA expression of VEGF after RME group increased from 1 to 7 days of experiment. mRNA expression of VEGF in the control group did not change at all. The data are shown as the fold increase of the corresponding 7 days of experiment. Results are expressed as percentage of controls (mean + S.D.; $n=5)$. Significant different from controls: ${ }^{*} \mathrm{p}<0.05 ;{ }^{* * * *} \mathrm{p}<0.001$.
EUA). TaqMan Gene Expression Assays was used to evaluate gene expressions as the second step in a two-step RT-PCR. Assays were done in $20 \mu \mathrm{L}$ single-plex reactions containing TaqMan Fast Universal PCR Master Mix, TaqMan Gene Expression Assays (primers and probes), distilled water and complementary DNA, according to the manufacturer's instructions (Applied Biosystems, Roche-Branchburg, NJ, USA). Amplification conditions included at $50{ }^{\circ} \mathrm{C}(2 \mathrm{~min})$, denaturation at $95^{\circ} \mathrm{C}(10 \mathrm{~min})$, and then run for 40 cycles at $95^{\circ} \mathrm{C}(15 \mathrm{~s})$ and $60^{\circ} \mathrm{C}(1 \mathrm{~min})$, followed by the standard denaturation curve on the CFX 96 Real-time PCR detection system (Bio-rad,California, USA). For mRNA analysis, the relative level of gene expression was calculated in reference to GAPDH expression using the cycle threshold (Ct) method. The threshold cycle ( $\mathrm{Ct}$ ) method was analysed by the $2-\Delta \Delta C T$ method.

\section{Statistical Analysis}

The data are expressed as the mean and standard deviation (SD) and it was perfomed in GraphPad Prism Statistics software, v5 (GraphPad Software Inc., San Diego, California, EUA). It was used Dahlberg's formula to fix some errors of the method based on the double measurements. Statistical differences among groups were evaluated with one-way analysis of variance (ANOVA) and Tukey's multiple comparison post-test. The level of significance was $p<0.05$.

\section{Results}

\section{Quantitative $R T-P C R$}

The effects of RME on VEGF and FGF-2 mRNA expression in palatal suture tissue are shown in Figs. 2 and 3. Intact suture tissue released high levels of angiogenic growth factors (VEGF and FGF-2) at approximately 1.01- and 1.07fold, respectively. The RME were found to induce VEGF gene expression in suture palatal tissue (Fig. 2). The analysis of the VEGF mRNA gene expression, after normalization by

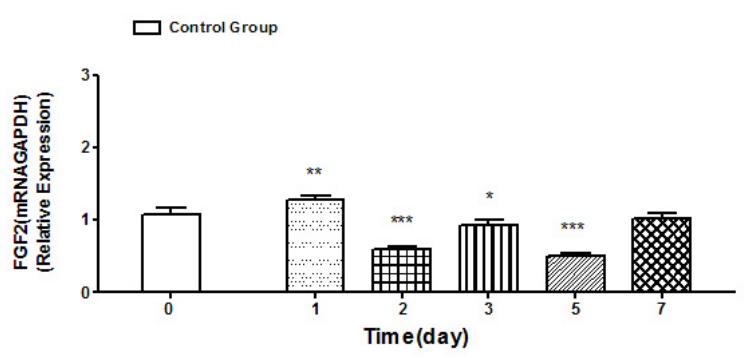

Figure 3. FGF-2 mRNA expression. mRNA expression of FGF-2 after RME group increased after $24 \mathrm{~h}$ and suddlenly decreased from 2 to 5 days of experiment. The data are shown as the fold increase at 7 days of experiment. mRNA expression of FGF-2 in the control group did not change at all. Results are expressed as percentage of controls (mean + S.D.; $\mathrm{n}=5$ ). Significant different from controls: ${ }^{*} \mathrm{p}<0.05 ;{ }^{* *} \mathrm{p}<0.01 ;{ }^{* * *} \mathrm{p}<0.001$. 
GAPDH, demonstrated that levels of VEGF mRNAs increased about $0.99 ; 0.56 ; 1.57 ; 0.28$ and 0.85 -fold after RME for $1,2,3,5$ and 7 days, respectively (Fig. 2). The levels of the FGF-2 mRNAs increased 0.20 -fold at 1 day and decreased about $0.48 ; 0.14 ; 0.57$ and 0.06 -fold after RME for $2,3,5$ and 7 days, respectively (Fig. 3 ).

The intact suture tissue released high levels of angiogenic growth factors (VEGF and FGF-2) about 1.01 and 1.07-fold respectively. After RME procedure the tissue samples showed a significant immediate increase on day 1 for VEGF and FGF-2 genes as compared to day 0 (control group). The increase was of $98,01 \%$ for VEGF and $19.62 \%$ for FGF-2. The increase of VEGF was obtained $24 \mathrm{~h}$ after RME and did not returned to initial values during the experimental fase. The upregulation FGF-2 expression was obtained $24 \mathrm{~h}$ after RME $(\mathrm{p}<0.001)$ and then returned to initial values at 7 days.

\section{Discussion}

The RME forces affect the dental and bone tissue inducing circulatory disturbances (16) and vascular changes. These effects are part of the inflammatory response. (17). Changes in oxygen levels in the dental tissue have also been attributed to circulatory disturbance following force application (18) and it is extremely complex. Inflammatory changes in the dental tissues are accompanied by release of several endogenous chemical mediators (e.g. prostanoids, and neuropeptides), vasodilatation process, increased vascular permeability and leukocyte extravasation (19). Several tissue reactions begins after RME procedure and it is similar to those observed in a wound healing process. These reactions may also involve a similar group of angiogenic growth factors.

During orthodontic tooth movement, a cascade of biochemically active factors is involved in the breakdown and regeneration of the supporting tissues. It has been observed that the type of tooth movement or force applied is not play an important key in blood vessels stimulation. Activation of the vascular system is the key factor (18). The magnitude of the force does not need to be excessive, even small forces of short duration of around $4 \mathrm{~h}$ may be adequate to evoke cellular responses (20). The data of the present research show the expression of VEGF and FGF-2 are significant upregulated at $24 \mathrm{~h}(\mathrm{p}<0.01)$ after RME and they are probably very important factors during the tissue healing after force application. These results indicate that VEGF and FGF-2 were released by the palatal suture tissue after RME, and they are involved in the angiogenic response after tissue damage.

When RME procedure on day 1 was compared to days 2-7, it was observed that continuous force application appeared to show a permanent angiogenic response in the suture tissue, although these results was reduced when compared to day 1 . The results suggest that growth factors are present in the palatal suture tissue over all periods of evaluation. The expressions at 2-7days was different from those values observed on early period of evaluation (day 1). It means that growth factors are upregulated at initial periods after RME procedure and the expression returns to baseline at day 7. At different periods of treatment, several angiogenic growth factors can be recruited in midpalatal tissues. The mediators signaling are based on stage of injury and healing, and the cells involved on each period of study.

Under mechanical stress, angiogenesis plays a key role in the healing process of the palatal suture tissue and is a determinant factor to bone tissue formation and deposition. Injured tissue cells secrete angiogenic growth factors to stimulate angiogenesis which precedes the reparative bone formation. VEGF is a crucial regulator of vascular development during embryogenesis (vasculogenesis) as well as in blood-vessel formation (angiogenesis) in tissues (13). VEGF has also been involved in the regulation of bone growth, remodeling and tooth movement with a prominent role in osteoclast differentiation and bone resorption (21). Derringer and Linden (14) reported that mechanical stress stimulates the production of VEGF.

In our study, the rate of increase in VEGF mRNA expression at $24 \mathrm{~h}$ was higher than the other groups. The high values during the fisrt day of the experiment could be due to the presence of the inflammatory infiltrate. The initial high level of VEGF can explain its persistance after 7 days in our study and highlights its role in angiogenesis during tissue healing after injury. In our study all experimental groups showed VEGF expression. Furthermore VEGF was expressed also in intact tissue (control group) with no signs of inflammation which suggests that VEGF was also produced in healthy dental tissue. Several authors $(2,8)$ suggested that this VEGF protein expression would be indicative of physiological angiogenesis and it plays an important role in maintaining homeostasis, which corroborates the findings of VEGF in the present research.

FGF-2 play a significant role in neovascularisation of damaged or traumatized tissue. Additionally, FGF-2 is a mitogen factor that is involved in fibroblast proliferation (22) and the recruitment of progenitor fibroblasts at the injury tissue (23). It is suggested that at certain times growth factors may act synergistically. On the other hand, the presence of one growth factor may be predominant while the production or binding of other factors declines. FGF-2 can regulate endothelial secretion of VEGF and have been reported a synergistic effects between FGF-2 
and VEGF in vitro (24). Simultaneously, interactions with inflammatory cells, neuropeptides and systemic hormones can occur (25). The reduced FGF-2 secretion after 2 two days observed in our study can affected the proliferation and the migration of progenitor palatal suture cells.

Researches revealed several studies evaluating the expression and role of VEGF and FGF-2 in the dental pulp (25) but there is no study about the expression of this protein after RME. So the present study clearly demonstrated that palatal suture cells secrete VEGF and FGF-2, particularly after injury (RME). The expression of these factors was on the initial periods of healing ( 1 day after injury) and corresponds well to the pathological changes in the palatal suture tissue following injury. The level of these factors returned to initial values after 7 day, mainly the FGF-2. The return to initial values only after 7 day confirms their very early potential effects on angiogenesis.

Although the results of RT-PCR showed an evident VEGF and FGF-2 expression on palatal suture after RME, it was suggested to conduct further studies to investigate the distribution of a couple of receptor after mechanical stress to elucidate bone remodeling process in midpalatal suture. $\vec{s}$ In addition, the possibility of using angiogenenic agents in orthodontic movement requires further investigations.

One limitation of this study is the short period of evaluation to understand the global process of bone healing that includes cell recruitment, angiogenesis and mineralization. For example we observed an increasing expression of VEGF over time, but we were not able to certify if the angiogenic molecular expression would be able to stabilize and the even effect of that on vessel sprouting.

In conclusion, the results of this study indicate that VEGF and FGF-2 growth factors released after RME and mechanical stress may play a role in the angiogenic response.

\section{Resumo}

Fator de crescimento endothelial (VEGF) e fator de crescimento de fibroblasto (FGF-2) tem a capacidade de aumentar a proliferação e permeabilidade vascular. 0 objetivo deste estudo foi quantificar a liberação dos dois fatores de crescimento (VEGF e FGF-2) após expansão rápida da maxilla (ERM). Trinta animais foram divididos aleatoriamente em dois grupos. Grupo Controle (5 ratos - sutura intacta) e grupos Experimentais (25 ratos submetidos a ERM) que foram avaliados em periodos diferentes de tratamento. Cinco animais foram eutanaziados em diferentes periodos de avaliação aos 0, 2, 3, 5 e 7 dias após ERM. RTPCR foi usado para avaliar a expressão gênica dos fatores de crescimento liberados nos diferentes períodos de estudo. Os dados foram submetidos à análise estatística usando ANOVA seguido do pós-teste de Tukey com nivel de significância de $\alpha=0.05$. RT-PCR mostrou que os RNAm de VEGF e FGF-2 estavam expressos na sutura palatina mediana intacta. Os RNAm de VEGF e FGF-2 foram estimulados nos periodos iniciais (24h) após ERM ( $p<0.001$ e $p<0.01$, respectivamente). Os nivies moleculares de VEGF nunca retornaram aos valores originais, e a expressão de FGF-2 reduziu até o dia $5(p<0.001)$ e de repente aumentou até o dia 7, retornando aos niveis originais. ERM aumentou a secreção de VEGF, mas diminuiu a secreção de FGF-2 quando comparado ao tecido intacto. Os resultados mostraram que estes fatores de crescimento são liberados e regulados na sutura palatina mediana após ERM e podem ser de importante contribuição para o entendimento da resposta reparadora geral do tecido da sutura durante o processo de remodelação óssea.

\section{Acknowledgments}

We gratefully acknowledge the Brazilian agencie FAPESP/CAPES for financial support.

\section{References}

1. Folkman J, Shing Y. Angiogenesis. J Biol Chem. 1992;267:10931-10934.

2. Booth V, Young S, Cruchley A, Taichman NS, Paleolog E. Vascular endothelial growth factor in human periodontal disease. J Periodontal Res 1998;33:491-499.

3. Kimoto T, Hosokawa R, Kubo T, Maeda M, Sano A, Akagawa Y. Continuous administration of basic fibroblast growth factor (FGF-2) accelerates bone induction on rat calvaria--an application of a new drug delivery system. J Dent Res 1998;77:1965-1969.

4. Klagsbrun M, D'Amore PA. Regulators of angiogenesis. Annu Rev Physiol 1991;53:217-239.

5. Gerwins P, Skoldenberg E, Claesson-Welsh L. Function of fibroblast growth factors and vascular endothelial growth factors and their receptors in angiogenesis. Crit Rev Oncol Hematol 2000;34:185-194.

6. Baffour R, Berman J, Garb JL, Rhee SW, Kaufman J, Friedmann P. Enhanced angiogenesis and growth of collaterals by in vivo administration of recombinant basic fibroblast growth factor in a rabbit model of acute lower limb ischemia: dose-response effect of basic fibroblast growth factor. J Vasc Surg 1992;16:181-191.

7. Kuroki M, Voest EE, Amano S, Beerepoot LV, Takashima S, Tolentino M, et al. Reactive oxygen intermediates increase vascular endothelial growth factor expression in vitro and in vivo. J Clin Invest 1996;98:1667-1675.

8. Senger DR, Galli SJ, Dvorak AM, Perruzzi CA, Harvey VS, Dvorak HF. Tumor cells secrete a vascular permeability factor that promotes accumulation of ascites fluid. Science 1983;219:983-985

9. Ferrara N. Vascular endothelial growth factor: basic science and clinical progress. Endocr Rev 2004;25:581-611.

10. Ferrara N. The role of vascular endothelial growth factor in pathological angiogenesis. Breast Cancer Res Treat 1995;36:127-137.

11. Li J, Perrella MA, Tsai JC, Yet SF, Hsieh CM, Yoshizumi M, et al. Induction of vascular endothelial growth factor gene expression by interleukin-1 beta in rat aortic smooth muscle cells. J Biol Chem 1995;270:308-312.

12. Midy V, Plouet J. Vasculotropin/vascular endothelial growth factor induces differentiation in cultured osteoblasts. Biochem Biophys Res Commun 1994;199:380-386.

13. Chu SC, Tsai CH, Yang SF, Huang FM, Su YF, Hsieh YS, et al. Induction of vascular endothelial growth factor gene expression by proinflammatory cytokines in human pulp and gingival fibroblasts. J Endod 2004;30:704707.

14. Derringer KA, Linden RW. Angiogenic growth factors released in human dental pulp following orthodontic force. Arch Oral Biol 2003;48:285-291.

15. Meikle MC. Remodeling the dentofacial skeleton: the biological basis of orthodontics and dentofacial orthopedics. J Dent Res 2007;86:12-24.

16. Nixon CE, Saviano JA, King GJ, Keeling SD. Histomorphometric study of dental pulp during orthodontic tooth movement. J Endod 1993;19:13-16.

17. Vandevska-Radunovic V. Neural modulation of inflammatory reactions in dental tissues incident to orthodontic tooth movement. A review of the literature. Eur J Orthod 1999;21:231-247.

18. Unsterseher RE, Nieberg LG, Weimer AD, Dyer JK. The response of human pulpal tissue after orthodontic force application. Am J Orthod Dentofacial Orthop 1987;92:220-224

19. Stashenko P, Teles R, D'Souza R. Periapical inflammatory responses and their modulation. Crit Rev Oral Biol Med 1998;9:498-521.

20. Roberts WE, Huja $S$, Roberts JA. Bone modeling - biomechanics, molecular mechanisms and clinical perspectives. Seminars in Orthodontic 
2004;10:123-161.

21. Kohno S, Kaku M, Tsutsui K, Motokawa M, Ohtani J, Tenjo K, et al. Expression of vascular endothelial growth factor and the effects on bone remodeling during experimental tooth movement. J Dent Res 2003;82:177-182.

22. Nakao K, Itoh M, Tomita Y, Tomooka Y, Tsuji T. FGF-2 potently induces both proliferation and DSP expression in collagen type I gel cultures of adult incisor immature pulp cells. Biochem Biophys Res Commun 2004;325:1052-1059.

23. Nugent MA, lozzo RV. Fibroblast growth factor-2. Int J Biochem Cell Biol 2000;32:115-120.
24. Goto F, Goto K, Weindel K, Folkman J. Synergistic effects of vascular endothelial growth factor and basic fibroblast growth factor on the proliferation and cord formation of bovine capillary endothelial cells within collagen gels. Lab Invest 1993;69:508-517.

25. Derringer KA, Linden RW. Vascular endothelial growth factor, fibroblast growth factor 2, platelet derived growth factor and transforming growth factor beta released in human dental pulp following orthodontic force. Arch Oral Biol 2004;49:631-641.

Received July 10, 2020 Accepted August 24, 2020 